\title{
Pengembangan Digibook Trigonometri Berbasis Flip PDF untuk Mengeksplor Kemampuan Koneksi Matematis Peserta Didik
}

\author{
Sofia Nida Khoerunnisa ${ }^{1}$, Nani Ratnaningsih ${ }^{2}$, Puji Lestari ${ }^{3}$ \\ 1, 2,3 Program Studi Magister Pendidikan Matematika, Universitas Siliwangi, \\ Jl. Siliwangi No 24, Kahuripan, Kec. Tawang, Kota Tasikmalaya, Jawa Barat \\ khoerunnisasofia@gmail.com
}

\begin{abstract}
The aim of this study to develop a flip PDF-based trigonometry digibookto explore mathematical connection abilities and to determine the effectiveness of Flip PDF-based trigonometry digibookto explore mathematical connection abilities. The method used in this study is a research and development method with the ADDIE model which goes through several stages, namely Analyze, Design, Develop, Implementation, and Evaluation to get a valid and usable product. The data collection techniques in this study used observation, learning media needs analysis questionnaires, student ability questionnaires, interviews, validation sheets given to 2 media experts and 2 material experts, user response questionnaires for individual trials given to 7 students of class X SMAN 11 Garut and 3 teachers. In mathematics, a limited trial questionnaire was given to 31 students of class X SMAN 11 Garut, then pretest and posttest for mathematical connection abilities. Based on the research results, this trigonometry digibookis valid and can be used from media experts and material experts. The results of individual trials and limited trials were obtained in the "good" category. The results of the effect size (ES) test obtained a value of 1.3 with the "strong effect" category. It can be concluded that the flip PDF-based trigonometry digibookis valid and can be used by students as a learning resource.
\end{abstract}

Keywords: Trigonometry Digibook, Connection Mathematics Ability.

\begin{abstract}
Abstrak
Penelitian ini bertujuan untuk mengembangkan digibook trigonometri berbasis flip PDF untuk mengeksplor kemampuan koneksi matematis dan mengetahui kualitas keefektifan digibook trigonometri berbasis Flip PDF untuk mengeksplor kemampuan koneksi matematis. Metode yang digunakan dalam penelitian ini adalah metode penelitian dan pengembangan (Research \& Development) dengan model pengembangan ADDIE yang melalui beberapa tahapan yaitu Analyze, Design, Develop, Implementation, dan Evaluation untuk mendapatkan produk yang valid dan dapat digunakan. Teknik pengumpulan data dalam penelitian ini menggunakan observasi, angket analisis kebutuhan media pembelajaran, angket kemampuan peserta didik, wawancara, lembar validasi yang diberikan kepada 2 ahli media dan 2 ahli materi, angket respon pengguna uji coba perorangan yang diberikan kepada 7 peserta didik kelas X SMAN 11 Garut dan 3 guru matematika, angket uji coba terbatas diberikan kepada 31 peserta didik kelas X SMAN 11 Garut, kemudian pretest dan posttest kemampuan koneksi matematis. Berdasarkan hasil penelitian, digibook trigonometri ini valid dan dapat digunakan dari ahli media dan ahli materi. Hasil uji coba perorangan dan uji coba terbatas diperoleh kategori "baik". Hasil pengujian effect size (ES) diperoleh nilai 1.3 dengan kategori "strong effect". Dapat disimpulkan bahwa digibook trigonometri berbasis flip PDF valid dan dapat digunakan oleh peserta didik sebagai sumber belajar.
\end{abstract}

Kata kunci: Digibook Trigonometri, Kemampuan Koneksi Matematis

Copyright (c) 2021 Sofia Nida Khoerunnisa, Nani Ratnaningsih, Puji Lestari

$\triangle$ Corresponding author: Sofia Nida Khoerunnisa

Email Address: khoerunnisasofia@gmail.com (Jl. Siliwangi No. 24, Tawang, Tasikmalaya, Indonesia)

Received 16 August 2021, Accepted 26 August 2021, Published 04 Oktober 2021

\section{PENDAHULUAN}

Pandemi COVID-19 yang mewabah secara global terus meningkat yang mengakibatkan perubahan berbagai aspek kehidupan manusia. Oleh karena itu, pembelajaran yang semula dengan tatap muka langsung berubah menjadi pembelajaran daring agar tujuan pembelajaran tetap tercapai. Berdasarkan Teori Vygotsky (dalam Hsieh, 2017) agar peserta didik mencapai kesuksesan dalam belajar perlu adanya Scaffolding (bantuan/dorongan yang diberikan oleh seorang ahli/guru). Scaffolding beroperasi dengan premis bahwa dukungan guru mengarahkan peserta didik untuk menjadi pembelajar 
mandiri (Vygotsky dalam Lange, Costley, \& Han, 2016). Peran guru dalam Teori Vygotsky ini adalah sebagai fasilitator. Guru lebih difokuskan untuk memberikan bantuan berupa teknik/keterampilan tertentu diluar batas kemampuan peserta didik. Scaffolding yang dapat diberikan kepada peserta didik dalam pembelajaran daring yaitu dengan penggunaan media pembelajaran.

Media pembelajaran sangat penting bagi seorang guru dalam menyampaikan materi pelajaran kepada peserta didik. Salah satu jenis media pembelajaran yaitu media pembelajaran interaktif. Menurut Patmawati, Ratnaningsih, \& Hermanto (2016) keunggulan penerapan media interaktif dalam menjelaskan suatu konsep dapat menuntut peserta didik untuk mengeksplorasi dan menganalisis, menjajaki dan menggali konsep tersebut serta prinsip-prinsip yang terdapat pada objek masalah. Selain itu, guru dituntut menguasai teknologi agar mudah dalam memilih dan mengembangkan media pembelajaran yang tepat dan efektif untuk diterapkan kepada peserta didik. Sesuai dengan pendapat Ratnaningsih, Ni'mah, \& Hidayat (2021) yang menyatakan bahwa sistem pembelajaran online di era digital ini menuntut guru untuk mengintegrasikan teknologi dalam pembelajaran.

Seiring dengan perkembangan zaman, kemajuan teknologi berkembang dengan sangat pesat yang dapat membantu kegiatan pembelajaran dengan memaksimalkan dan mengembangkan penggunaan media pembelajaran yang sesuai. Salah satu hasil pengembangan teknologi yaitu digibook (digital book) yang merupakan buku yang dipadukan dengan alat elektronik yang dapat memuat konten multimedia sehingga pembelajaran lebih interaktif walaupun tanpa kehadiran guru sekalipun. Digibook dikembangkan dengan lebih menekankan pada aspek interaktivitas dan keterpaduan konten media (Mawarni \& Muhtadi, 2017). Terdapat beberapa software yang dapat digunakan untuk membuat digibook, salah satunya adalah Flip PDF yang memiliki banyak kelebihan, salah satunya mudah digunakan terutama bagi pemula yang tidak mengetahui bahasa pemrograman. Oleh karena itu, dalam penelitian ini menggunakan Flip PDF untuk mengembangkan digibook.

Salah satu materi pelajaran yang sulit untuk dipahami bagi peserta didik dalam mata pelajaran matematika adalah materi Trigonometri. Hal ini sejalan dengan pendapat Mensah (2017) peserta didik mengalami kesulitan dalam menyederhanakan masalah Trigonometri dan memahami perbandingan Trigonometri. Kesulitan yang dialami peserta didik yang terbanyak adalah pada materi trigonometri yang dianggap merupakan materi hapalan yang banyak menggunakan rumus dan sulit untuk dipahami (Shofiah, Lukito, \& Siswono, 2018). Menurut Rawa, Sutawidjaja, dan Sudirman (2016) yang menyatakan bahwa kesulitan peserta didik terhadap materi Trigonometri salah satunya disebabkan oleh rendahnya kemampuan koneksi matematis. Selain itu, hasil penelitian yang dilakukan oleh Widiyawati, Septian, dan Inayah (2020) menunjukkan kemampuan koneksi matematis peserta didik pada materi trigonometri termasuk kategori rendah.

Trigonometri merupakan materi yang mengaitkan ide-ide matematis baik dengan matematika itu sendiri maupun dengan disiplin ilmu lain, serta penerapannya tidak terlepas dari dunia nyata. Koneksi matematis dapat meningkatkan kemampuan kognitif peserta didik seperti mengingat, memahami penerapan suatu konsep pada lingkungan dan lain sebagainya, tanpa menerapkan konsep tersebut pada 
pembelajaran, akan sulit untuk mengingat materi dan konsep terpisah, sedangkan matematika kaya akan prinsip (Siregar \& Surya, 2017). Sesuai dengan pendapat Hidayat, Ratnaningsih, \& Santika (2019) yang menyatakan bahwa kemampuan koneksi matematis akan membantu peserta didik memahami keterkaitan antar konsep-konsep matematika. Oleh karena itu, diperlukan suatu media pembelajaran untuk materi trigonometri yang dapat mengeksplor kemampuan koneksi peserta didik.

Berdasarkan hasil wawancara yang dilakukan terhadap seorang guru matematika di SMAN 11 Garut, beliau menyatakan bahwa dalam pelaksanaan pembelajaran daring hanya menggunakan dan mengoptimalkan media yang sudah tersedia seperti Youtube, Whatsapp, dan Zoom Meeting. Oleh karena itu, peneliti tertarik untuk melakukan penelitian dan pengembangan digibook yang dapat memuat konten multimedia. Selain itu, guru matematika tersebut menyatakan bahwa kegiatan pembelajaran daring yang dilaksanakan pada masa pandemi COVID-19 ini berdampak pada kemampuan peserta didik dalam mengaitkan konsep atau ide matematis dan kemampuan peserta didik dalam menyelesaikan masalah dalam kehidupan sehari-hari seperti pada materi trigonometri. Di sisi lain, materi trigonometri sangat penting karena teorema dan konsep trigonometri diperlukan untuk mengembangkan keterampilan berpikir kreatif, logis, dan analitis peserta didik (Dündar, 2015). Oleh karena itu, peneliti tertarik untuk melakukan penelitian dan pegembangan digibook trigonometri untuk mengeksplor kemampuan koneksi matematis.

Beberapa penelitian sebelumnya sudah mengembangkan digibook diantaranya menggunakan software Kvisoft Flip book Maker (Divayana, Suyasa, Ariawan, Mahendra, \& Sugiharni, 2019); penelitian yang menggunakan software EPUB (Prasetya, Wibawa, \& Hirashima, 2018); penelitian yang menggunakan software Adobe Indesign (Mawarni \& Muhtadi, 2017). Berbagai penelitian tentang Trigonometri juga telah banyak dilakukan (Nurafni, Pujiastuti, \& Mutaqin, 2020; Rahmawati, Anggraini, \& Masykur, 2019; Cahyono, Tsani, \& Rahma, 2018). Selain itu, beberapa penelitian tentang kemampuan koneksi matematis juga telah banyak dilakukan (Widiyawati, Septian, \& Inayah, 2020; Sholekah, Anggreini, \& Waluyo, 2017; Rawa, Sutawidjaja, \& Sudirman, 2016). Namun pengembangan digibook pada materi Trigonometri dengan berbasis Flip PDF untuk mengeksplor kemampuan koneksi matematis belum ditemukan. Oleh karena itu, penelitian ini bertujuan untuk membahas secara komprehensif mengenai prosedur pengembangan digibook trigonometri berbasis Flip PDF untuk mengeksplor kemampuan koneksi matematis peserta didik, serta untuk mengetahui kualitas efektivitas digibook Trigonometri berbasis Flip PDF untuk mengeksplor kemampuan koneksi matematis peserta didik.

\section{METODE}

Penelitian ini dilakukan di SMAN 11 Garut. Metode penelitian yang digunakan dalam penelitian ini adalah metode penelitian dan pengembangan (Research and Development). Tujuan metode penelitian pengembangan ini digunakan untuk menghasilkan produk tertentu dalam menguji keefektifan produk tersebut, maka diperlukan penelitian untuk menguji keefektifan produk tersebut (Sugiyono, 
2017). Pada penelitian ini dikembangkan digibook yang memuat materi Trigonometri. Model yang digunakan dalam pengembangan ini adalah model ADDIE (Branch, 2010) yang terdiri dari 5 tahapan yaitu: (1) Analyze (analisis), tahap ini dilakukan untuk mengidentifikasi suatu permasalahan yang diperoleh melalui observasi, angket, dan wawancara untuk menganalisis kebutuhan media pembelajaran dan menganalisis materi pelajaran, (2) Design (perancangan), tahap ini berisi rencana yang akan dilakukan dalam penelitian dan pengembangan diantaranya yaitu membuat flowchart, membuat storyboard, mempersiapkan instrumen tes berdasarkan indikator kemampuan koneksi matematis, merancang lembar validasi untuk ahli materi dan ahli media, merancang angket respon pengguna untuk guru matematika dan peserta didik, serta mempersiapkan isi digibook dan mendesain setiap halaman digibook pada powerpoint (3) Develop (pengembangan), tahap ini merupakan tahap pengembangan dari tahap desain, kegiatan yang dilakukan pada tahap ini adalah ini menghasilkan produk sesuai rancangan, melakukan uji validasi media kepada 2 orang ahli media, dan uji validasi materi kepada 2 orang ahli materi, kemudian melakukan revisi berdasarkan saran dan komentar dari para ahli untuk mendapatkan produk yang valid, (4) Impelementation (implementasi), tahap ini merupakan pengaplikasian produk, kegiatan yang dilakukan pada tahap ini melakukan uji coba perorangan yang dilakukan kepada 3 guru matematika dan 7 peserta didik kelas X SMAN 11 Garut yang dipilih secara purposive yaitu pertimbangan guru dengan kriteria kemampuan peserta didik dalam mengemukakan pendapat/jalan pikirannya sehingga dapat memberikan informasi yang lengkap dan jelas, kemudian uji coba terbatas yang dilakukan kepada 31 peserta didik kelas X MIPA 5 SMAN 11 Garut, dan (5) Evaluation (evaluasi), pada tahap ini melakukan penyempurnaan produk dari hasil analisis data pada tahap-tahap sebelumnya. Berikut ini prosedur penelitian dan pengembangan digibook trigonometri untuk mengeksplor kemampuan koneksi matematis.

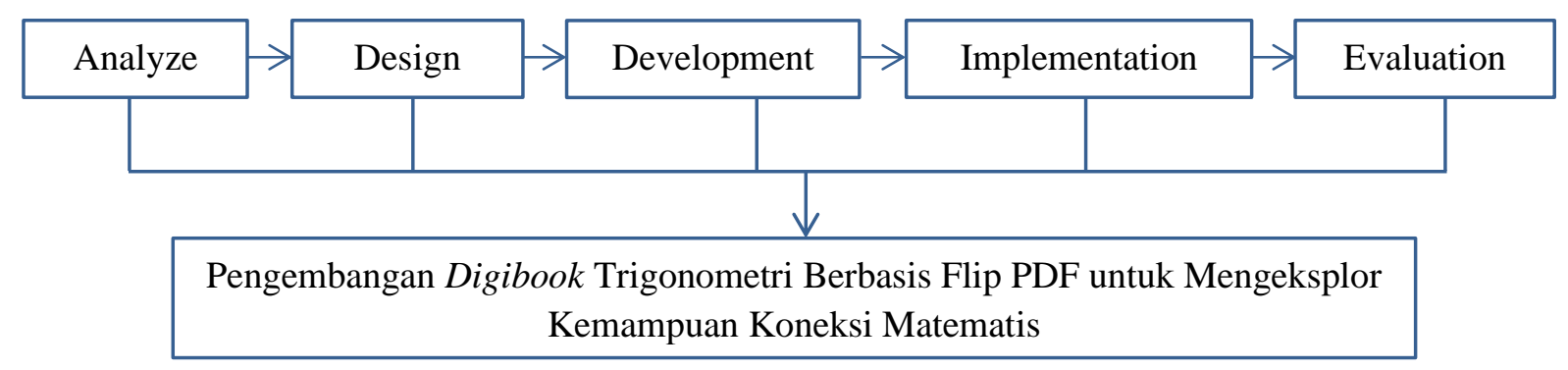

Gambar 1. Prosedur Penelitian dan Pengembangan

Teknik pengumpulan data dalam penelitian ini adalah observasi yang dilakukan pada tahap analisis, angket kebutuhan untuk menganalisis kebutuhan media pembelajaran dan menganalisis materi pelajaran, wawancara yang dilakukan pada tahap analisis setelah pemberian angket, validasi ahli yaitu ahli materi dan ahli media pembelajaran untuk memperoleh produk yang valid, angket respon pengguna untuk mendapatkan data terkait respon/tanggapan guru dan peserta didik terhadap kualitas dari penampilan digibook, dan tes kemampuan koneksi matematis untuk mengetahui kualitas efektivitas 
produk yang dikembangkan. Instrumen yang digunakan dalam penelitian ini adalah angket kebutuhan media pembelajaran untuk guru dan peserta didik, angket untuk analisis materi pelajaran, lembar validasi untuk ahli materi, lembar validasi untuk ahli media, angket respon pengguna, dan soal tes kemampuan koneksi matematis. Semua instrumen yang digunakan dalam penelitian ini sudah layak digunakan. Teknik analisis data dalam penelitian ini adalah deskriptif kualitatif, diantaranya yaitu mendeskripsikan hasil observasi, angket, dan wawancara pada tahapan analisis, mendeskripsikan hasil validasi ahli media dan ahli materi untuk menentukan kevalidan produk, mendeskripsikan hasil angket respon pengguna, serta melakukan perhitungan uji Effect size (ES) untuk mengetahui kualitas efektivitas produk yang dikembangkan

\section{HASIL DAN DISKUSI}

Penelitian dan pengembangan ini diawali dengan tahap analisis. Kegiatan yang dilakukan pada tahapan analisis, yaitu melakukan observasi, memberikan angket kepada seorang guru matematika dan peserta didik kelas X MIPA 5 SMAN 11 Garut yang berjumlah 31 peserta didik, serta melakukan wawancara kepada guru matematika diperoleh kesimpulan bahwa dibutuhkan sebuah media pembelajaran yang dapat meningkatkan minat belajar peserta didik. Media pembelajaran tersebut juga harus mudah diakses dan mudah digunakan oleh peserta didik. Salah satu jenis media pembelajaran yang memenuhi kriteria tersebut adalah digibook (digital book) yang disajikan dalam bentuk html sehingga sangat mudah untuk diakses dan digunakan baik itu di smartphone maupun laptop hanya dengan satu kali klik. Media pembelajaran tersebut diperlukan untuk membantu peserta didik dalam memahami materi trigonometri. Selain itu, dibutuhkan media pembelajaran yang dapat mengeksplor kemampuan koneksi matematis karena materi trigonometri merupakan materi yang berkaitan dengan satu sama lain, juga berkaitan dengan mata pelajaran lain dan penerapannya tidak terlepas dalam kehidupan nyata. Koneksi matematis akan membantu peserta didik dalam mempelajari materi trigonometri. Oleh karena itu, peneliti mengembangkan produk digibook trigonometri untuk mengeksplor kemampuan koneksi matematis.

Tahap selanjutnya adalah tahap design (perancangan), dimana peneliti membuat flowchart atau menyusun alur pembuatan digibook trigonometri yang kemudian dijadikan dasar dalam pengembangan storyboard; dari flowchart tersebut, peneliti membuat storyboard atau rancangan pembuatan digibook yang berisi detail gambaran program digibook trigonometri; mempersiapkan instrumen tes berdasarkan indikator kemampuan koneksi matematis, soal tes ini diberikan kepada peserta didik saat pretest dan posttest untuk mengetahui kualitas efektivitas digibook trigonometri untuk mengeksplor kemampuan koneksi matematis; serta merancang lembar penilaian (sebagai alat pengumpulan data validasi media dan materi) dan merancang angket respon pengguna untuk peserta didik dan guru. Kemudian, peneliti menyusun materi, membuat contoh soal, dan membuat latihan soal dengan bantuan microsoft word, membuat video pembelajaran dengan menggunakan microsot powerpoint dan screen recorder smartphone, mencari karakter-karakter, gambar-gambar, animasi-animasi dan icon-icon di internet. 
Setelah semua bagian-bagian digibook sudah siap, peneliti menggabungkan bagian-bagian tersebut menjadi satu kesatuan dengan menggunakan powerpoint. Dengan bantuan powerpoint, peneliti membuat background, membuat lay out, dan mendesain setiap halaman sedemikian hingga sangat menarik untuk dilihat.

Setelah tahap design selesai, maka tahap selanjutnya adalah tahap development (pengembangan), yaitu menghasilkan produk yang sebelumnya telah dirancang pada tahap sebelumnya. File digibook dalam bentuk powerpoint yang sudah didesain pada tahap sebelumnya, disimpan dalam format .pdf. File pdf tersebut di edit agar menjadi sebuah digital book dengan bantuan software Flip PDF untuk menambahkan animasi, video, audio, dan untuk memfungsikan tombol-tombol. Setelah selesai, digibook tersebut di publish online dengan format html. Berikut digibook trigonometri yang dikembangkan.

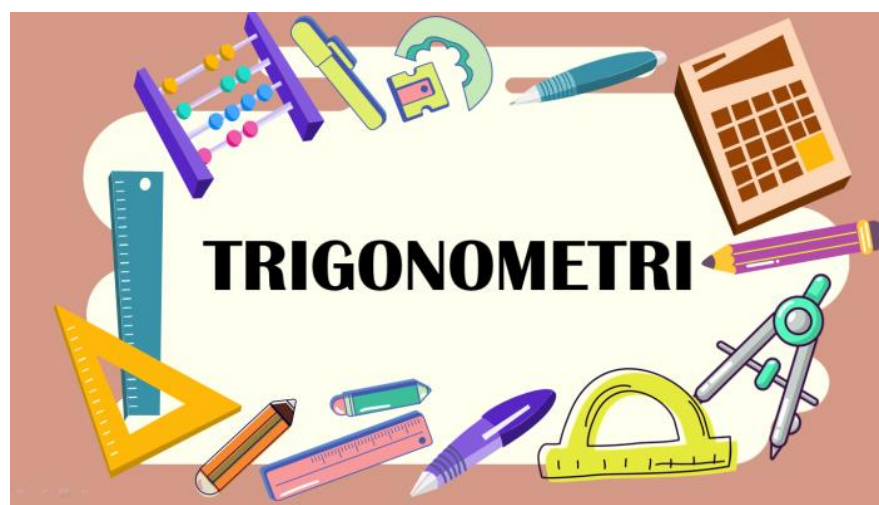

Gambar 2. Cover Digibook Trigonometri

Setelah cover, halaman selanjutnya adalah kata-kata motivasi (Gambar 3) yang diharapkan dapat memacu peserta didik untuk belajar lebih giat. Kemudian menu home (Gambar 4) yang berisi pilihan bab materi dari digibook Trigonometri. Satu materi memiliki warna background yang sama. Background masing-masing materi diantaranya, yaitu: rasio trigonometri pada segitiga siku-siku berwarna biru muda; rasio trigonometri sudut-sudut di berbagai kuadran dan sudut-sudut berelasi berwarna kuning muda; aturan sinus dan cosinus berwarna hijau muda; dan fungsi trigonometri dan grafiknya berwarna merah muda.

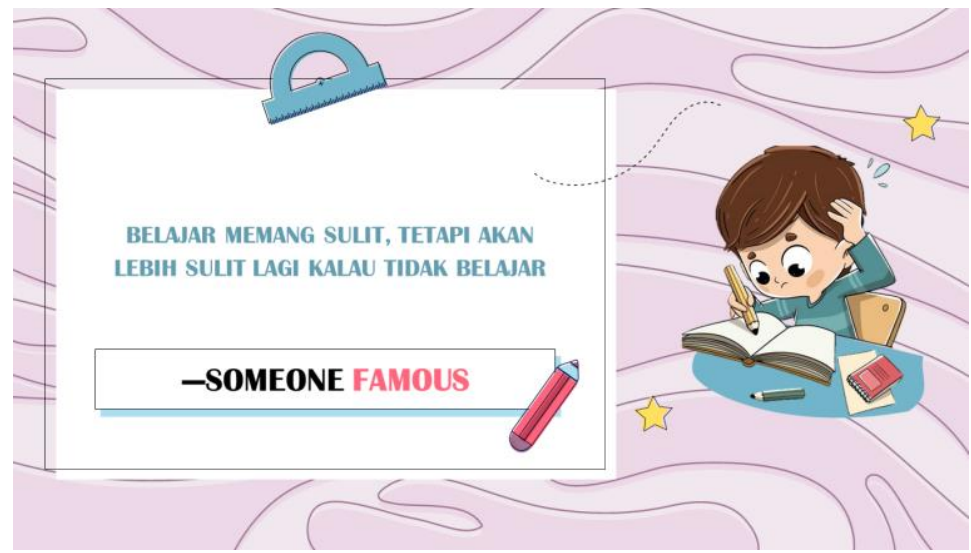

Gambar 3. Tampilan Setelah Cover 


\section{TRIGONOMETRI}

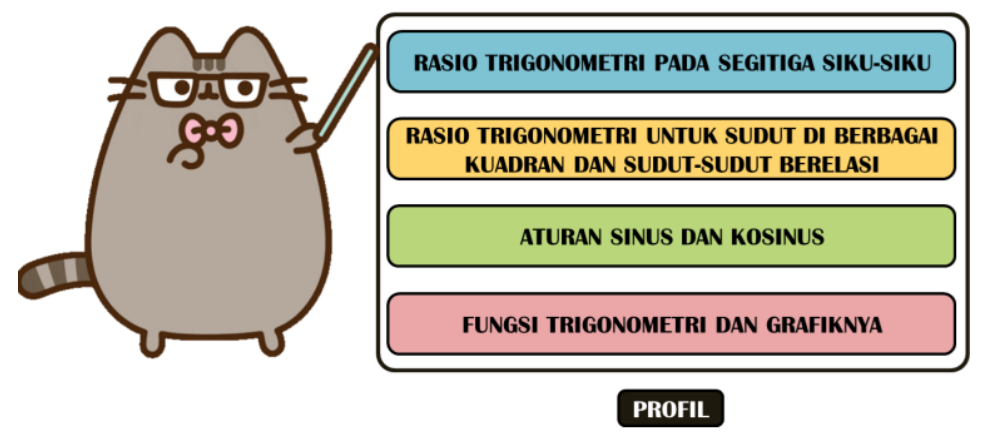

Gambar 4. Menu Digibook Trigonometri

Ketika salah satu materi dipilih, maka akan muncul tampilan seperti pada Gambar 5 yang terdapat beberapa pilihan menu yang dapat diakses. Serta, terdapat tombol home pada bagian bawah yang memudahkan untuk menuju menu pilihan bab materi (Gambar 4).

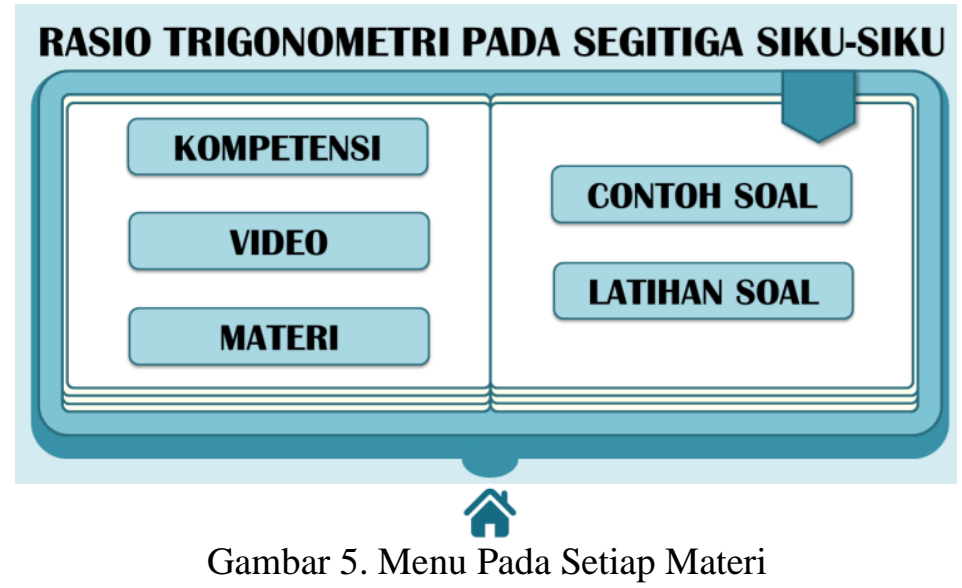

Tampilan yang muncul ketika "Kompetensi" pada Gambar 5 dipilih yang akan menampilkan pilihan antara Kompetensi Inti dan Kompetensi Dasar pada Gambar 6. Terdapat dua tombol, yaitu tombol home dan tombol book yang berfungsi untuk menuju menu pada setiap materi seperti Gambar 5. Kompetensi Inti dan Kompetensi dasar memiliki desain tampilan yang sama seperti Gambar 7 di bawah ini. Terdapat tiga tombol yaitu book, home, dan back yang berfungsi untuk kembali ke menu kompetensi (Gambar 6).

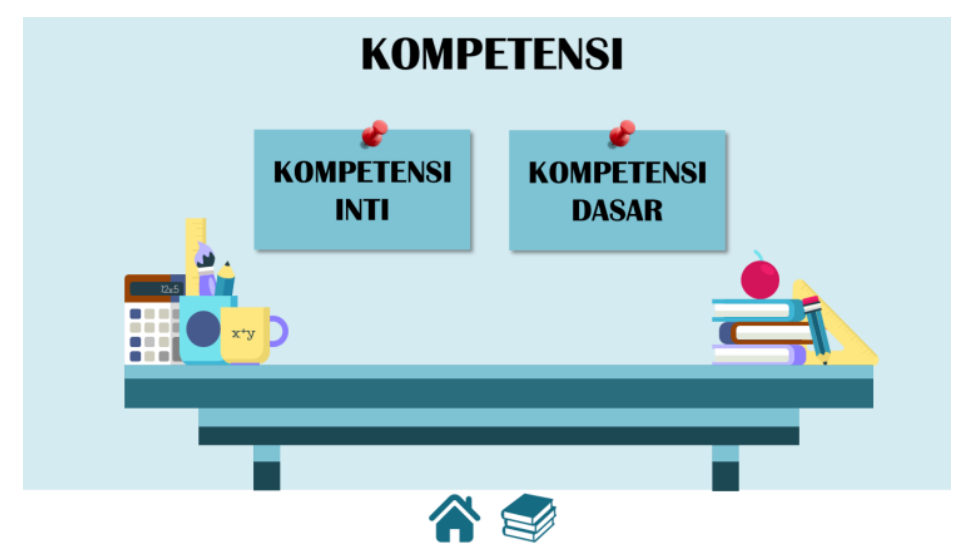

Gambar 6. Menu Kompetensi 


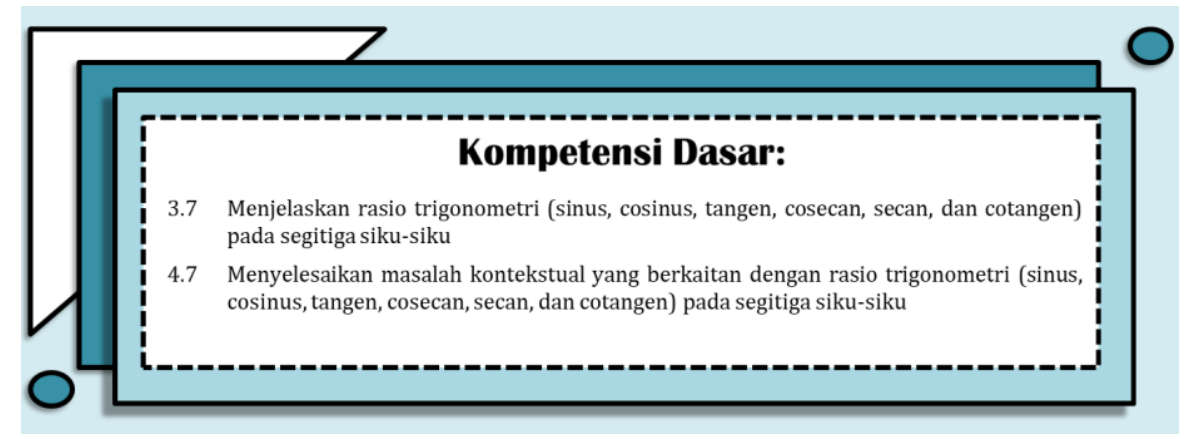

Gambar 7. Tampilan Kompetensi

Tampilan yang muncul ketika "Video" pada Gambar 5 dipilih, masing-masing materi memiliki desain video yang berbeda, salah satunya seperti Gambar 8. Video pada digibook ini dibuat oleh peneliti sendiri dengan berbantuan powerpoint untuk membuat slide isi video beserta animasi-animasi, kemudian menguunakan fitur screen recorder yang terdapat pada smartphone untuk membuat video.

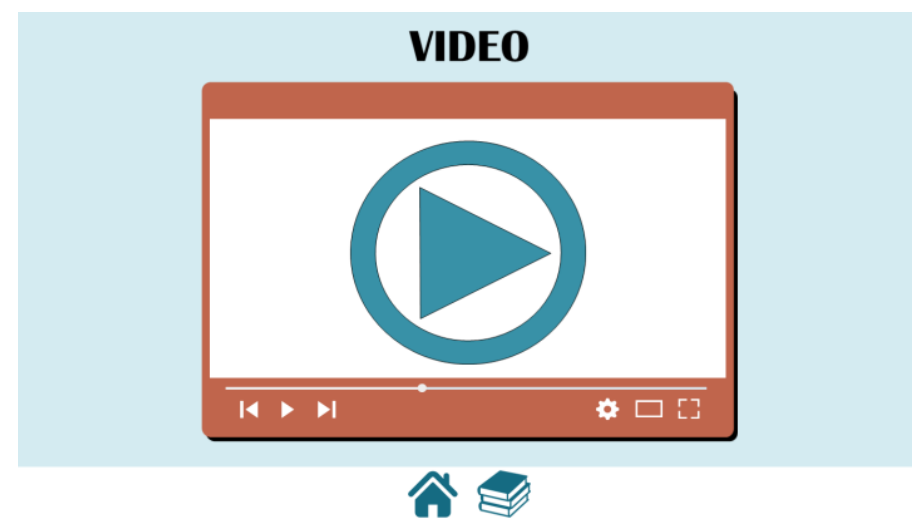

Gambar 8. Tampilan Menu Video

Tampilan yang muncul ketika "Materi" dipilih, terdapat beberapa sub materi yang dapat dipilih. Begitu pula tiga materi lainnya juga terdapat beberapa sub materi yang dipilih. Masing-masing setiap materi memliki tampilan desain warna yang berbeda, salah satunya seperti Gambar 9. Isi materi mempunyai desain yang berbeda pada setiap halamannya, berikut tampilan salah satu halaman isi materi pada Gambar 10 yang terdapat 3 tombol, yaitu book, home, dan opened book yang berfungsi untuk menuju ke menu sub materi (Gambar 9).

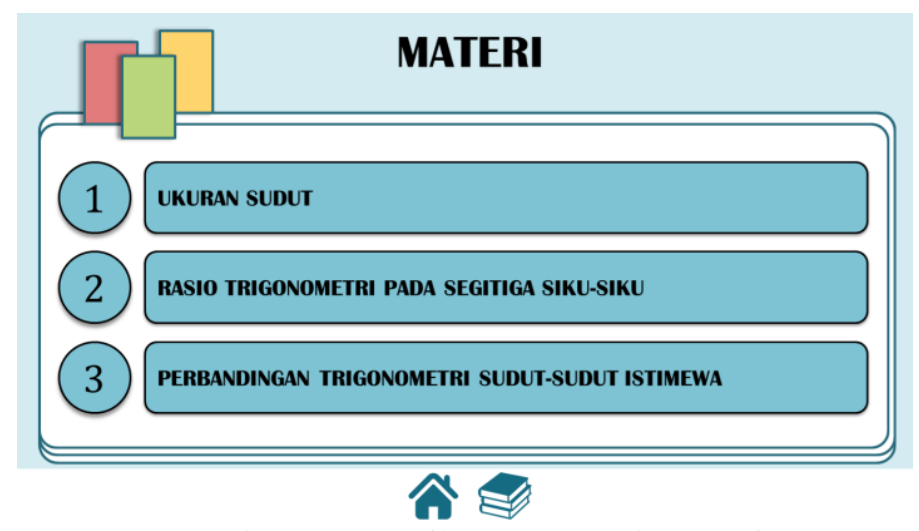

Gambar 9. Tampilan Menu Sub Materi 


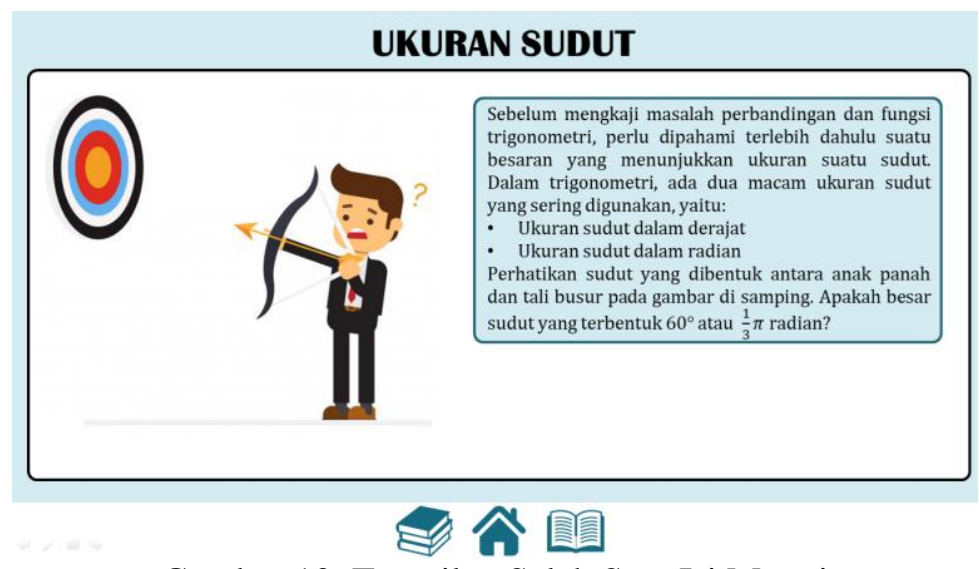

Gambar 10. Tampilan Salah Satu Isi Materi

Tampilan desain contoh soal memiliki desain yang berbeda pada setiap materi, salah satunya tampak seperti pada Gambar 11. Soal dan pembahasan terdapat pada halaman yang berbeda agar peserta didik dapat mengerjakannya terlebih dahulu, kemudian memeriksa jawabannya dengan memperhatikan pembahasan yang ada pada digibook. Contoh soal yang disusun berdasarkan indikator kemampuan koneksi matematis.

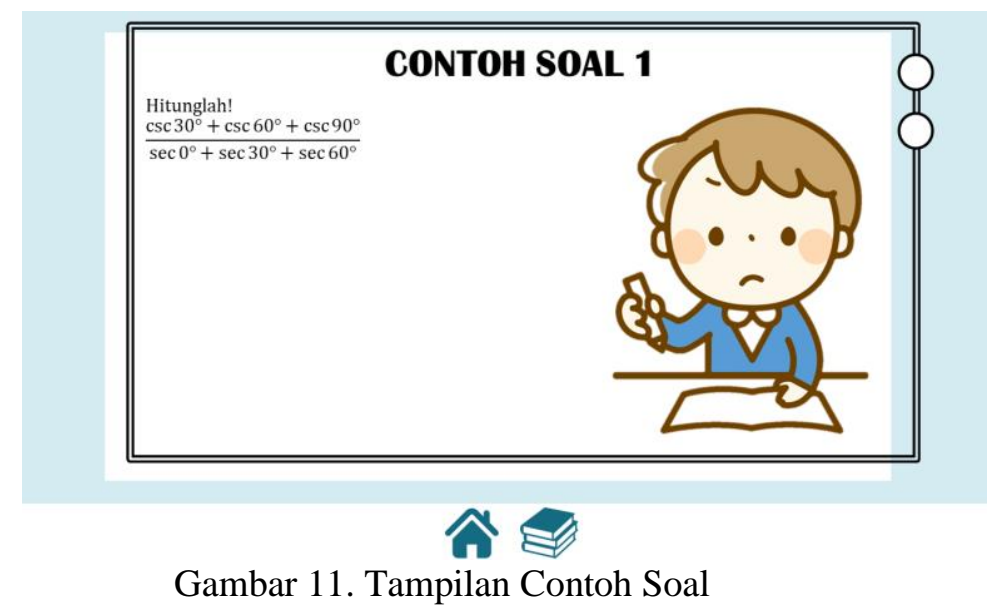

Selanjutnya yaitu latihan soal yang masing-masing setiap bagian materi terdapat 6 latihan soal yang disusun berdasarkan indikator kemampuan koneksi matematis Menu latihan soal juga memiliki desain yang berbeda untuk setiap materi, salah satunya tampak seperti Gambar 12. Untuk memulai mengerjakan soal, peserta didik dapat mengklik "Latihan Soal (Klik disini)".

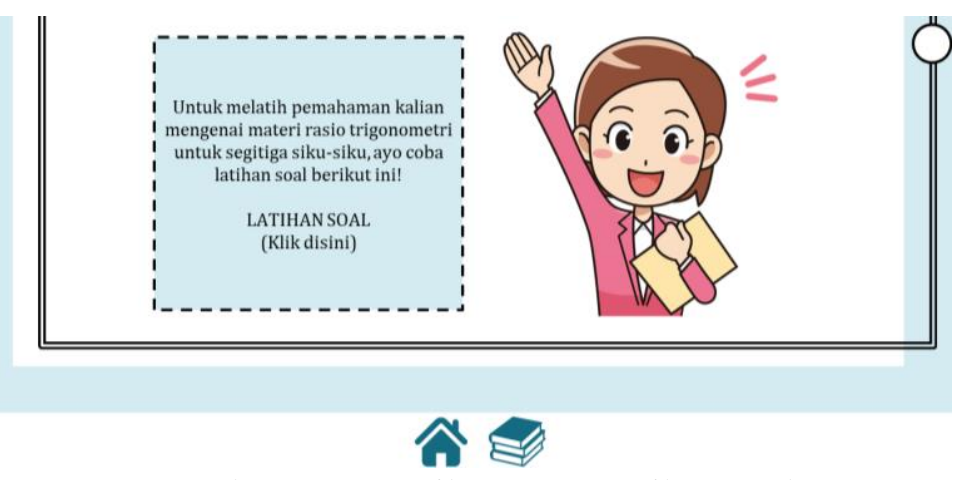

Gambar 12. Tampilan Menu Latihan Soal 
Ketika latihan soal diklik, akan muncul tampilan seperti pada Gambar 13. Angka sebelah kiri yang berwarna hijau merupakan jumlah soal yang dijawab benar, angka sebelah kanan yang berwarna merah merupakan jumlah soal yang dijawab salah. Setelah peserta didik selesai mengerjakan semua soal, kemudian akan muncul skor yang diperoleh dalam bentuk persen (\%).
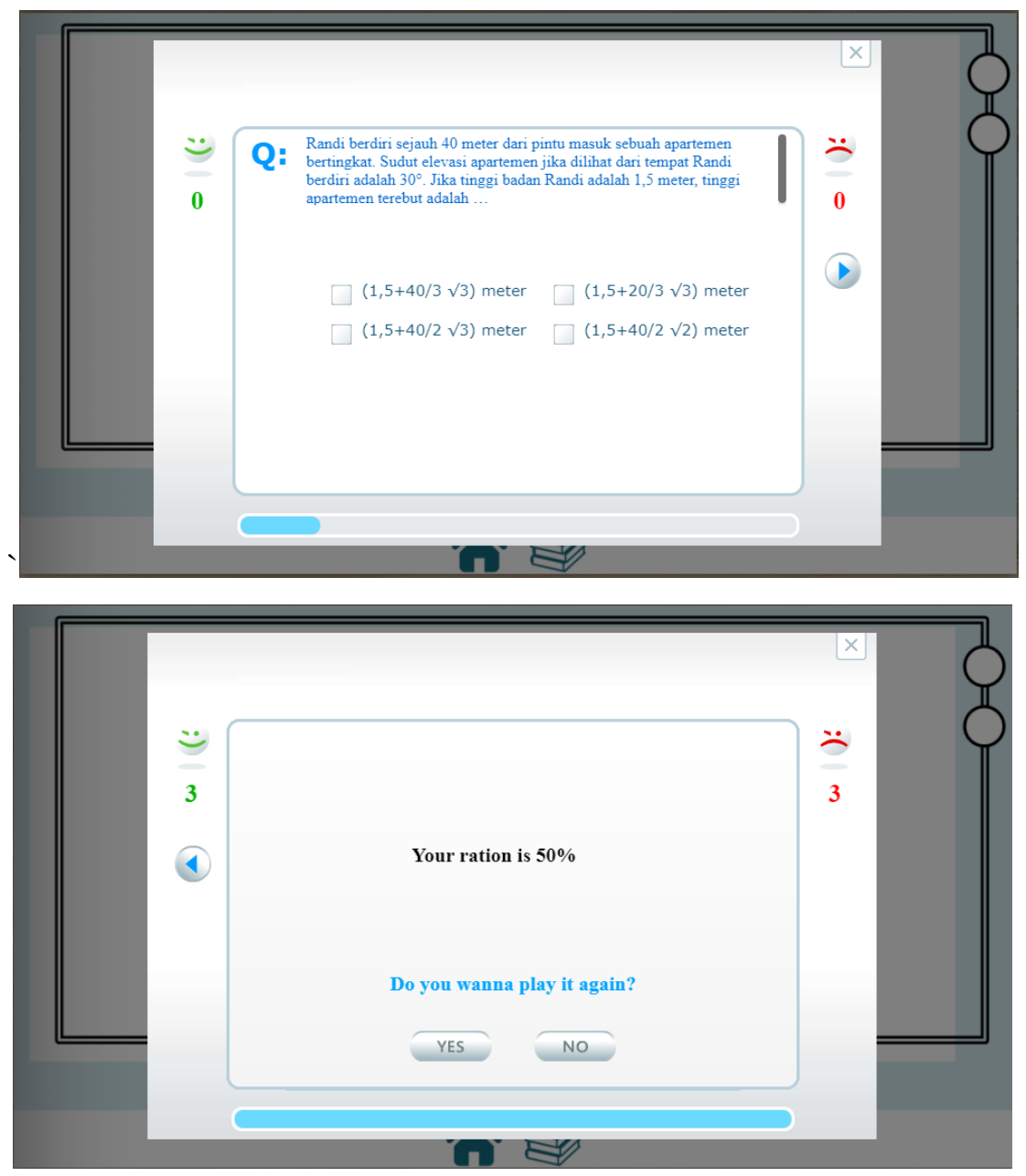

Gambar 13. Latihan Soal

Selain itu, peneliti juga membuat petunjuk penggunaan digibook agar memudahkan pengguna dalam menggunakan digibook yang berisi cara mengakses digibook, memaksimalkan tampilan digibook, dan manfaat tombol-tombol yang ada. Selanjutnya dilakukan validasi oleh para ahli media dan ahli materi yang bertujuan untuk mendapatkan saran dan masukan guna untuk perbaikan digibook yang telah dikembangkan. pemilihan validator ditentukan berdasarkan keahlian di bidang yang sesuai pada digibook yang telah dikembangkan kepada 2 orang ahli media dan 2 orang ahli materi. Validasi yang telah dilakukan peneliti sebanyak dua kali.

Pada validasi tahap ke-1, kedua validator media memberikan kesimpulan penilaian secara umum" dapat digunakan dengan perbaikan". Sedangkan untuk validator materi praktisi pendidik memberikan kesimpulan penilaian secara umum "dapat digunakan dengan perbaikan" dan validator 
materi dosen memberikan kesimpulan penilaian secara umum "dapat digunakan tanpa perbaikan". Terdapat beberapa hal yang perlu diperbaiki dari ahli media, yaitu backsound harus ganti-ganti, menambahkan petunjuk untuk mematikan suara musik, memperbaiki warna yang kurang serasi, dan mensinkronkan musik. Sedangkan, dari ahli materi yang perlu diperbaiki adalah pertanyaan pada bagian materi rasio trigonometri untuk sudut di berbagai kuadran dan sudut-sudut berelasi, serta memperbaiki kesalahan penomoran Kompetensi Dasar pada materi fungsi trigonometri dengan menggunakan lingkaran satuan. Hasil saran dari para ahli dan hasil perbaikan disajikan pada tabel berikut.

Tabel 1. Saran dan Hasil Perbaikan

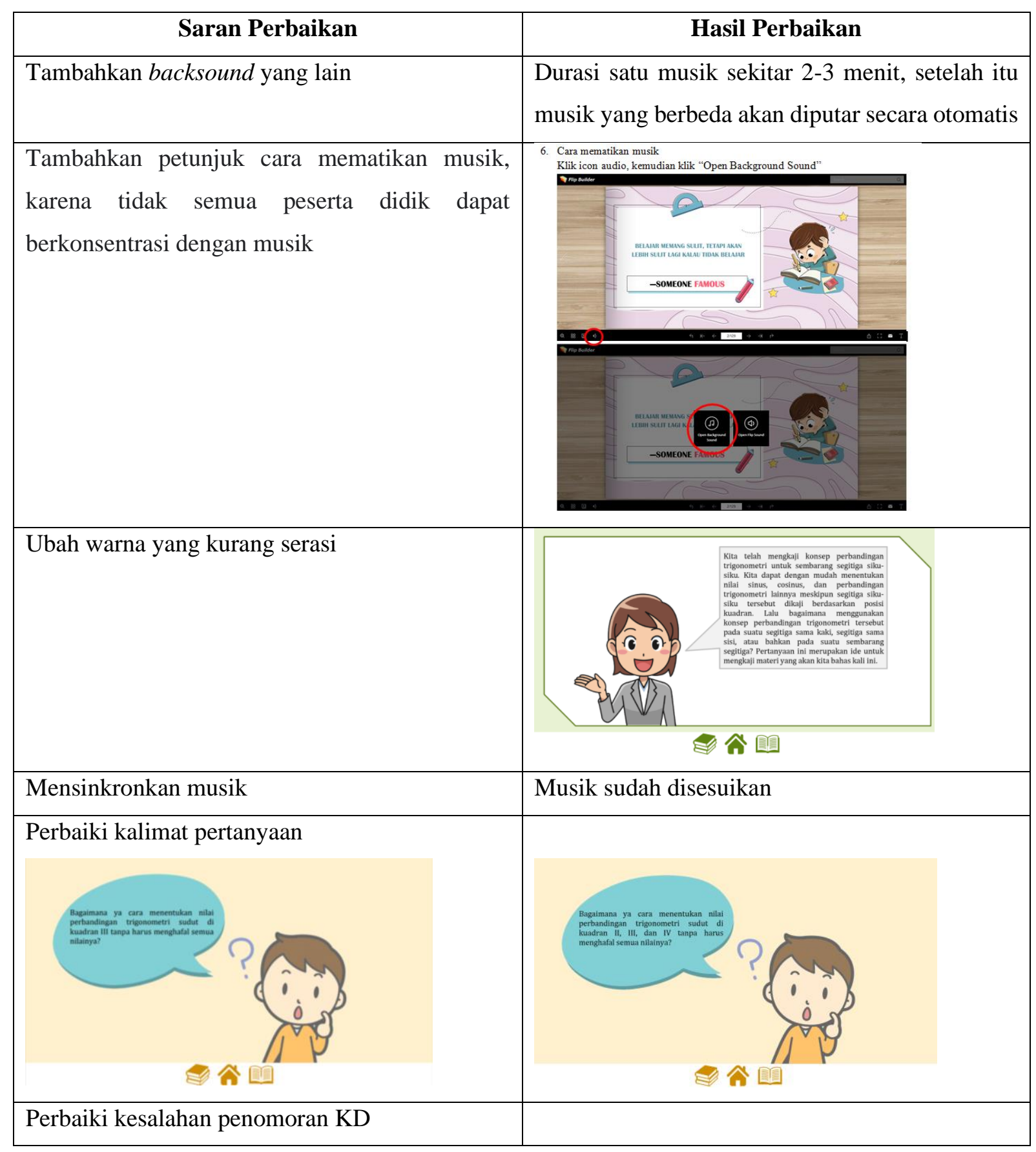




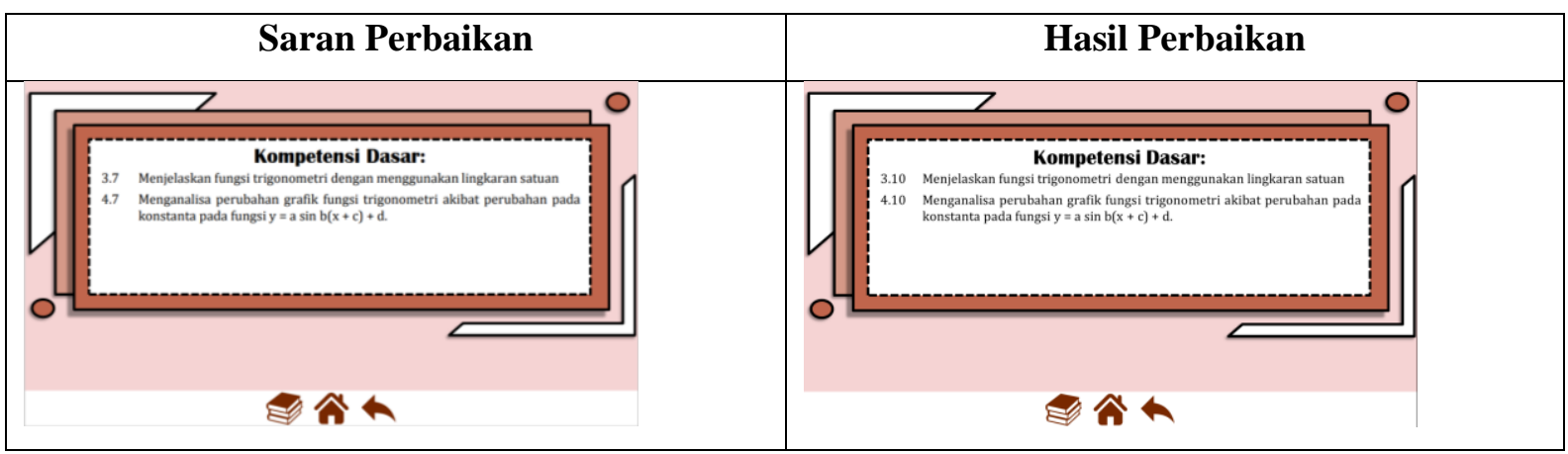

Langkah selanjutnya adalah validasi tahap ke 2, setelah produk direvisi dan diperbaiki sesuai saran dan masukan pada validasi tahap ke 1. Pada validasi tahap ke 2, baik validator materi maupun validator media memberikan penialian pada setiap pernyataan valid dengan kesimpulan penilaian secara umum "dapat digunakan tanpa perbaikan".

Setelah produk dinyatakan valid dan dapat digunakan tanpa perbaikan, langkah selanjutnya adalah melakukan uji coba perorangan dan uji coba terbatas di SMAN 11 Garut. Untuk mengukur tingkat keterbacaan dan kemenarikan produk, maka dilakukan uji coba perorangan yang melibatkan 7 orang peserta didik yang dipilih secara purposive dan 3 orang guru matematika, serta uji coba terbatas yang melibatkan 31 orang peserta didik. Masing-masing peserta didik dan guru matematika diberikan angket respon pengguna yang telah disusun dengan rentang nilai 1 sampai 5. Pada uji coba perorangan peserta didik tersebut diperoleh skor total sebesar 263 dengan kriteria "baik". Sedangkan, uji coba perorangan guru matematika memperoleh skor total 116 dngan kriteria "baik". Setelah itu, peneliti melakukan uji coba terbatas diperoleh skor total 1159 dengan kategori "baik". Sesuai dengan penelitian yang dilakukan oleh Yayuk, Kuncahyono, \& Restian (2017) yang menunjukkan peserta didik merespon dengan baik dalam proses pembelajaran dan merasa senang belajar dengan menggunakan digibook karena media lebih menarik.

Tahap selanjutnya adalah evaluation (evaluasi), pada peneliti melakukan penyempurnaan produk dengan mamperhatikan masukan dan saran dari berbagai pihak agar digibook yang dikembangkan semakin berkualitas dan dapat memberikan manfaat sesuai dengan tujuan pengembangan. Hasil dari tahap ini merupakan evaluasi dari hasil analisis data pada tahap-tahap sebelumnya, yang menunjukkan hasil akhir produk digibook trigonometri untuk mengeksplor kemampuan koneksi matematis yang valid dan dapat digunakan sebagai sumber belajar. Digibook ini berisi kompetensi, materi, video, contoh soal, latihan soal, serta profil pengembang. Penyajian digibook dalam bentuk html yang mudah diakses dengan satu kali klik yang dapat mempermudah peserta didik dalam belajar dimanapun dan kapanpun.

Selanjutnya peneliti mengukur kualitas efektivitas digibook trigonometri berbasis Flip PDF untuk mengsekplor kemampuan koneksi matematis dengan didasarkan dari nilai pretest dan posttest yang dilakukan pada awal pembelajaran dan akhir pembelajaran peserta didik. Pretest diberikan kepada peserta didik pada awal pertemuan untuk mengetahui kemampuan awal peserta didik. Selama 
pembelajaran trigonometri, peserta didik menggunakan digibook trigonometri sebagai sumber belajar. Setelah peserta didik belajar dan memahami materi trigonometri, peneliti memberikan posttest. Dari hasil pretest dan posttest diperoleh data berikut.

mean of posttest $=78,54839$

mean of pretest $=66,45161$

standard deviation of pretest $=9,326803$

$E S=\frac{\text { mean of posttest }- \text { mean of pretest }}{\text { standard deviation of pretest }}$

$E S=\frac{78,54839-66,45161}{9,326803}$

$\mathrm{ES}=1,29699$

$\mathrm{ES}=1.3$

Berdasarkan hasil perhitungan effect size, diperoleh bahwa nilai ES sebesar 1.3 yang termasuk dalam klasifikasi strong effect (Cohen, Manion, \& Marrison, 2007). Artinya, digibook yang dikembangkan dapat menjadi sumber belajar baru yang menarik bagi peserta didik. Selain itu, digibook tersebut didukung dengan adanya keterbaharuan yaitu dapat diakses dengan smartphone/laptop/komputer, tersedia video, dan latihan soal yang sesuai dengan indikator kemampuan koneksi matematis. Sesuai dengan penelitian yang dilakukan oleh Marselina \& Muhtadi (2019) yang menyimpulkan bahwa produk buku digital efektif untuk meningkatkan hasil belajar peserta didik.

\section{KESIMPULAN}

Digibooktrigonometri berbasis Flip PDF untuk mengeskplor kemampuan koneksi matematis yang telah dikembangkan menggunakan model pengembangan ADDIE termasuk dalam kategori valid dan layak digunakan berdasarkan penilaian dari ahli media dan ahli materi. Respon guru dan peserta didik terhadap digibook trigonometri tersebut memperoleh respon dengan kategori baik berdasarkan hasil uji coba perorangan dan uji coba terbatas. Selain itu, kualitas efektivitas digibook trigonometri berbasis Flip PDF untuk mengeksplor kemampuan koneksi matematis memperoleh nilai effect size sebesar 1.3 yang berada pada kategori "strong effect", sehingga digibook trigonometri sangat efektif untuk digunakan dalam pembelajaran.

\section{REFERENSI}

Branch, R. M. (2010). Instructional design: The ADDIE approach. In Instructional Design: The ADDIE Approach. https://doi.org/10.1007/978-0-387-09506-6

Cahyono, B., Tsani, D. F., \& Rahma, A. (2018). Pengembangan Buku Saku Matematika Berbasis Karakter pada Materi Trigonometri. Jurnal Phenomenon, 08(2), 185-199.

Cohen, L., Manion, L., \& Morrison, K. (2007). Experiments, quasi-experiments, single-case research 
and meta-analysis. In Research Methods in Education. https://doi.org/10.4324/9780203029053-23

Divayana, D. G. H., Suyasa, P. W. A., Ariawan, I. P. W., Mahendra, I. W. E., \& Sugiharni, G. A. D. (2019). The Design of Digital book Content for Assessment and Evaluation Courses by Adopting Superitem Concept Based on Kvisoft Flipbook Maker in era of Industry 4.0. Journal of Physics: Conference Series, 1165(1), 0-6. https://doi.org/10.1088/1742-6596/1165/1/012020

Dündar, S. (2015). Mathematics teacher-candidates' performance in solving problems with different representation styles: The trigonometry example. Eurasia Journal of Mathematics, Science and Technology Education. https://doi.org/10.12973/eurasia.2015.1397a

Hidayat, E., Ratnaningsih, N., \& Santika, S. (2019). Pemetaan gaya berpikir peserta didik berdasarkan kemampuan koneksi matematis. Prosiding Seminar Nasional \& Call For Papers, 738-748.

Hsieh, Y. C. (2017). A case study of the dynamics of scaffolding among ESL learners and online resources in collaborative learning. Computer Assisted Language Learning. https://doi.org/10.1080/09588221.2016.1273245

Lange, C., Costley, J., \& Han, S. L. (2016). Informal cooperative learning in small groups: The effect of scaffolding on participation. Issues in Educational Research.

Marselina, V., \& Muhtadi, A. (2019). Pengembangan buku digital interaktif matematika pada materi geometri. Jurnal Inovasi Teknologi Pendidikan, 6(2), 196-207.

Mawarni, S., \& Muhtadi, A. (2017). Pengembangan digital book interaktif mata kuliah pengembangan multimedia pembelajaran interaktif untuk mahasiswa teknologi pendidikan. Jurnal Inovasi Teknologi Pendidikan. https://doi.org/10.21831/jitp.v4i1.10114

Mensah, F. S. (2017). Ghanaian senior high school students ' error in learning of trigonometry ghanaian senior high school students, error in learning of trigonometry. International Journal of Environmental \& Science Education.

Nurafni, A., Pujiastuti, H., \& Mutaqin, A. (2020). Pengembangan Bahan Ajar Trigonometri Berbasis Kearifan Lokal. Journal of Medives: Journal of Mathematics Education IKIP Veteran Semarang, 4(1), 71. https://doi.org/10.31331/medivesveteran.v4i1.978

Patmawati, H., Ratnaningsih, N., \& Hermanto, R. (2016). Developing Character Based Interactive L Earning Media To Facilitate Student ' S Self - Learning of Capita Selecta Mathematics ( a Research on Mathematical Critical and Creative Thinking Skills of Mathematics Departement Studentof Teacher Training and Education. 1(2008), 523-532.

Prasetya, D. D., Wibawa, A. P., \& Hirashima, T. (2018). An interactive digital book for engineering education students. World Transactions on Engineering and Technology Education.

Rahmawati, A., Anggraini, D., \& Masykur, R. (2019). Pengembangan Modul Berbasis POE (Predict Observe Explain) Pada Materi Trigonometri. Kreano, Jurnal Matematika Kreatif-Inovatif, 10(2), 193-201. https://doi.org/10.15294/kreano.v10i2.20337

Ratnaningsih, N., Ni'Mah, K., \& Hidayat, E. (2021). Covid-19 the Earliest for Digital Learning in Mathematics: An Overview from Technology Literacy. Journal of Physics: Conference Series, 
1819(1). https://doi.org/10.1088/1742-6596/1819/1/012027

Rawa, N., Sutawidjaja, A., \& Sudirman. (2016). Kemampuan Koneksi Matematis Siswa Kelas X Pada Materi Perbandingan Trigonometri. Pengembangan 4C's Dalam Pembelajaran Matematika: Sebuah Tantangan Dalam Pengembangan Kurikulum Matematika, 911-923.

Shofiah, S., Lukito, A., Yuli, T., \& Siswono, E. (2018). Pembelajaran Learning Cycle 5E Berbasis Pengajuan Masalah untuk Meningkatkan Hasil Belajar Siswa Kelas X pada Topik Trigonometri. Kreano: Jurnal Matematika Kreatif-Inovatif, $\quad 9(1), \quad$ 54-62. https://doi.org/10.15294/kreano.v9i1.9856

Sholekah, L. M., Anggreini, D., \& Waluyo, A. (2017). Analisis Kesulitan Siswa Dalam Menyelesaikan Soal Matematika Ditinjau Dari Koneksi Matematis Materi Limit Fungsi. Wacana Akademika: Majalah Ilmiah Kependidikan. https://doi.org/10.30738/wa.v1i2.1413

Sugiyono. (2017). Metode Penelitian Pendidikan Pendekatan Kauntitatif, Kualitatif, R\&D. Bandung: Alfabeta

Widiyawati, W., Septian, A., \& Inayah, S. (2020). Analisis Kemampuan Koneksi Matematis Siswa SMK Pada Materi Trigonometri. Jurnal Analisa. https://doi.org/10.15575/ja.v6i1.8566

Yayuk, E., Kuncahyono, K., \& Restian, A. (2017). Pendampingan Penyusunan Media Pembelajaran Digibook (Buku Digital) di SDN Girimoyo 2 Kabupaten Malang. Publikasi Pendidikan, 7(3), 134. https://doi.org/10.26858/publikan.v7i3.3513 